\title{
HUMIRON® IS AN EFFECTIVE BIODEGRADABLE SOURCE OF CHELATED IRON FOR PLANTS: AN IRON-59 UPTAKE STUDY
}

\author{
MIROSLAV NIKOLIĆ ${ }^{1 *}$ \\ ${ }^{1}$ Institute for Multidisciplinary Research, University of Belgrade, Belgrade, Serbia
}

\begin{abstract}
Here we tested plants' ability to use iron (Fe) from the water-soluble commercial product Humiron® (a complex of Fe with highly purified and solubilized humic acids extracted from leonardite) as a source of chelated Fe for both strategy 1 (e.g. cucumber) and strategy 2 (e.g. barley) plant species grown under low Fe conditions. Iron from radioactive ${ }^{59}$ Fe-labelled Humiron ${ }^{\circledR}$ can easily be acquired by strategy 1 plant species via reduction of Fe ${ }^{\mathrm{III}}$ by the inducible plasma membrane-bound reductase, similarly to the reduction of synthetic Fe ${ }^{\text {III }}$-chelates. Strategy 2 plant species can also efficiently utilize Fe from Humiron ${ }^{\circledR}$ via ligand exchange between humates and phytosiderophores (PS). Moreover, the efficacy of Humiron ${ }^{\circledR}$ is comparable to Fe complexed with waterextractable humic substances obtained form peat. Being easily biodegradable this product can be used as an effective Fe source for organic crop production.
\end{abstract}

Keywords: Barley, Chlorosis, Cucumber, Humate Complex, Iron Root-acquisition Strategies, Transport.

\section{INTRODUCTION}

Even though the fourth most abundant mineral element in the Earth's crust, iron (Fe) in soils occurs mostly in the insoluble $\mathrm{Fe}^{\mathrm{III}}$ forms which are unavailable to plants. The concentrations of available $\mathrm{Fe}$ from the $\mathrm{Fe}$ chelated compounds (e.g. Fe humates) in most well-aerated soils are often lower than required for an adequate plant growth, especially at neutral and alkaline soil $\mathrm{pH}$ (Römheld \& Nikolic, 2006). According to Römheld \& Marschner (1994), higher plants respond to a lack of Fe by developing two different strategies. Dicots and nongraminaceous monocots employ the strategy 1 response on low soluble $\mathrm{Fe}$ in the rhizosphere by: 1) release more protons, thereby decrease rhizosphere $\mathrm{pH}$ and increase Fe solubility ( $A H A l$ genes coding for a plasma membrane $\mathrm{H}^{+}$-ATPase), and 2) induction of plasma membrane-bound $\mathrm{Fe}^{\mathrm{III}}$-chelate reductase (encoded by FRO genes), which is followed by the uptake of $\mathrm{Fe}^{2+}$ via an inducible IRT1 transporter. Strategy 2 plants, which include all grasses (Poaceae), release low-molecular-weight compounds, so-called phytosiderophores (PS) that chelate $\mathrm{Fe}^{3+}$ ions, and take up the $\mathrm{Fe}^{\mathrm{III}}$-PS complex via the root YS1 transporters (for review see Nikolic \& Pavlovic, 2018).

The use of various commercial synthetic Fe-chelates, i.e. $\mathrm{Fe}$ complexed with ethylenediaminetetraacetate (EDTA) or ethylenediamine-di-o-hydroxyphenylacetate (EDDHA), as soil amendment is a frequent measure for remedy of for $\mathrm{Fe}$ deficiency chlorosis in agricultural practice (Römheld \& Nikolic, 2006). However, their costs and the environmental risk of leaching and groundwater pollution by heavy metals may limit the interest for these products, particularly in sustainable agriculture. On the other hand limited number of organic acidic

* Corresponding author: mnikolic@imsi.bg.ac.rs BIOLOGY anions (e.g. citrate and malate) are able to form stable complexes with $\mathrm{Fe}^{\mathrm{III}}$, which are however highly degradable by soil microbes and/or also photo labile (Cesco et al., 2002; Römheld \& Nikolic, 2006). Some naturally occurring Fe-chelates in soils, such as $\mathrm{Fe}$ chelated to the microbial siderophores (e.g. Fe $\mathrm{F}^{\mathrm{III}}$ - dihydroxamate; Hördt et al., 2000) as well as humic substances, could be an alternative to synthetic $\mathrm{Fe}$-chelates. It has been demonstrated that the roots of both strategy 1 and strategy 2 plants can utilize $\mathrm{Fe}$ bound to the water-extractable humic substances (WEHS; e.g. Pinton et al., 1999; Cesco et al., 2002).

In this work we tested plants' ability to use Fe from the water-soluble commercial product Humiron ${ }^{\circledR}$ as a source of chelated $\mathrm{Fe}$ for both the strategy 1 and the strategy 2 plant species. Thus, the major objective was to study the possible mechanisms involved in utilization of $\mathrm{Fe}$ from the radioactive ${ }^{59} \mathrm{Fe}$-labelled $\mathrm{Fe}$-humate product in Humiron ${ }^{\circledR}$, by cucumber (strategy 1) and barley (strategy 2) plants subjected to nutrient solution model experiments.

\section{MATERIALS AND METHODS}

Humiron ${ }^{\circledR}$ (kindly provided by HUMINTECH GmbH, Düsseldorf, Germany) is a complex of $\mathrm{Fe}$ with highly purified and solubilized humic acids extracted from leonardite (an oxidized form of lignite, a byproduct of coal mining).

The experiments were carried out according to the methodology previously described by Cesco et al. (2002). After germination in quartz sand moistened with saturated $\mathrm{CaSO}_{4}$, cucumber (Cucumis sativus L., cv. Chinese long) and barley (Hordeum vulgare L., cv. Europa) seedling were transferred to the complete nutrient solutions as reported by Cesco et al. (2002), either without $(-\mathrm{Fe})$ or with $(+\mathrm{Fe}) 50 \mu \mathrm{M}$ Fe-EDTA. The nutrient solutions were renewed completely every $3 \mathrm{~d}$ and continuously aerated. Plants were grown for $7 \mathrm{~d}$ under controlled 
environmental conditions in a growth chamber with light/dark regime of $16 / 8 \mathrm{~h}$, temperature regime of $24 / 20^{\circ} \mathrm{C}$, photon flux density of approximately $300 \mu^{-2} \mathrm{~mol}^{-1}$ at plant height and relative humidity of about $70 \%$.

Determination of $\mathrm{Fe}^{\mathrm{III}}$ reduction capacity by intact cucumber roots was carried out in an assay solution containing $0.5 \mathrm{mM} \mathrm{CaSO}_{4}, 1 \mu \mathrm{M} \mathrm{Fe}$ (supplied as either Fe-EDTA or Humiron ${ }^{\circledR}$ ), $200 \mu \mathrm{M}$ bathophenanthrolinedisulfonate (BPDS), and $10 \mathrm{mM}$ Mes/NaOH (pH 6.0) or $10 \mathrm{mM}$ Hepes/NaOH $(\mathrm{pH}$ 7.8) for $30 \mathrm{~min}$ in darkness. Reduction rates were determined as a formed red $\mathrm{Fe}^{\mathrm{II}}(\mathrm{BPDS})_{3}$ complex by measuring absorbance at $535 \mathrm{~nm}$ against blanks (without roots) and using an extinction coefficient of $22.14 \mathrm{mM}^{-1} \mathrm{~cm}^{-1}$ for calculation (Nikolic et al., 2007).

In ${ }^{59} \mathrm{Fe}$ uptake experiments, Fe-chelates were labelled by mixing ${ }^{59} \mathrm{FeCl}_{3}$ with either Humiron ${ }^{\circledR}$ or Fe-EDDHA (specific radioactivity $0.2 \mu \mathrm{Ci} \mu \mathrm{mol}^{-1} \mathrm{Fe}$ ) following the procedure previously described by Nikolic et al. (2000). The final concentration of $\mathrm{Fe}$ in the uptake solutions was $1 \mu \mathrm{M}$. For cucumber plants the ${ }^{59} \mathrm{Fe}$-labelled uptake solution was buffered at pH 6.0 with $10 \mathrm{mM} \mathrm{Mes} / \mathrm{NaOH}$ or at $\mathrm{pH} 7.8$ with $10 \mathrm{mM}$ Hepes $/ \mathrm{NaOH}$, and the uptake period was $6 \mathrm{~h}$. For barley plants, the uptake lasted $4 \mathrm{~h}$ and was performed in the morning (period of high PS release; $2 \mathrm{~h}$ after onset of light) or in the evening (period of low PS release; $12 \mathrm{~h}$ after onset of light). Additionally, 2'-deoxymugineic acid (DMA) collected from the exudates of Fe-deficient barley roots and purified following the method of Awad et al. (1988) was added in the uptake solution at final concentration of $20 \mu \mathrm{M}$ during evening experiment.

After the uptake periods, the plants were transferred to a freshly prepared ${ }^{59} \mathrm{Fe}$-free nutrient solution for $10 \mathrm{~min}$ and then harvested. The extraplasmatic ${ }^{59} \mathrm{Fe}$ pool was removed by reductive incubation of roots with $1.5 \mathrm{mM}$ bipyridyl and $7.5 \mathrm{mM}$ sodium dithionite (Bienfait et al., 1985; Cesco et al., 2002). Roots and shoots were oven-dried at $80^{\circ} \mathrm{C}$, weighed, ashed at $550^{\circ} \mathrm{C}$, and suspended in $1 \%(\mathrm{w} / \mathrm{v}) \mathrm{HCl}$ for ${ }^{59} \mathrm{Fe}$ determination by a liquid scintillation counting.

\section{RESULTS AND DISCUSSION}

Preculture of cucumber plants in Fe-free nutrient solution for 7 days induced $\mathrm{Fe}^{\mathrm{III}}$ reductase activity in the roots for both $\mathrm{Fe}$ chelates (i.e. Fe-EDTA and Humiron ${ }^{\circledR}$ ), which was 4-5 times higher compared to the plants grown in nutrient solution adequately supplied with Fe (Fig. 1). The root reduction capacity for Humiron ${ }^{\circledR}$ was about $20 \%$ lower than that measured for $\mathrm{Fe}$ EDTA as a substrate. It has been shown that $\mathrm{Fe}^{\mathrm{III}}$ complexed with WEHS can easily be reduced at the plasma membrane of both root and leaf cells (Cesco et al., 2000, 2002; Nikolic et al., 2003). Exposure of $-\mathrm{Fe}$ roots to high $\mathrm{pH}$ of the root medium decreased the $\mathrm{Fe}^{\mathrm{III}}$ reduction capacity for both Fe chelates by 3-4 times as compared to the roots at low $\mathrm{pH}$. The measured reduction rates were comparable to $+\mathrm{Fe}$ roots at $\mathrm{pH}$ 6.0. These findings undoubtedly confirm that Humiron ${ }^{\circledR}$ is a suitable $\mathrm{Fe}^{\mathrm{III}}$ chelate substrate for $\mathrm{Fe}^{\mathrm{III}}$ reduction via a plasma membraneassociated low-Fe-inducible $\mathrm{Fe}^{\mathrm{III}}$ reductase.

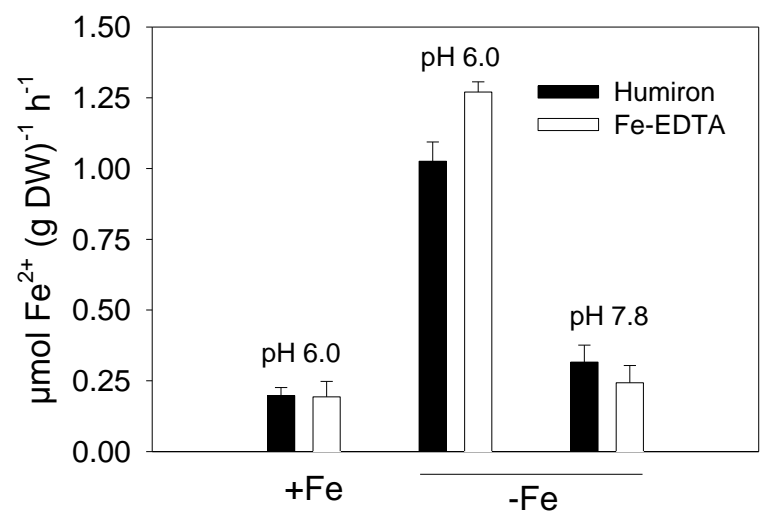

Figure 1. Fe $\mathrm{F}^{\mathrm{III}}$-chelate reduction capacity of cucumber roots for Humiron ${ }^{\circledR}\left(\mathrm{Fe}^{\mathrm{III}}\right.$-humate complex) and $\mathrm{Fe}^{\mathrm{III}}$-EDTA (control) as affected by rhizosphere $\mathrm{pH}$ and $\mathrm{Fe}$ nutritional status.

Both high root $\mathrm{pH}$ (7.8) and addition of BPDS (strong $\mathrm{Fe}^{2+}$ scavenger) inhibited $\mathrm{Fe}$ uptake and root-to-shoot translocation of Fe from ${ }^{59} \mathrm{Fe}$-labelled Humiron ${ }^{\circledR}$ in $-\mathrm{Fe}$ cucumber plants (Fig. 2 ), indicating that the preceding $\mathrm{Fe}^{\mathrm{III}}$ reduction of Humiron ${ }^{\circledR}$ (see Fig. 1) was a necessary step for the uptake of $\mathrm{Fe}^{2+}$ by $\mathrm{Fe}$ deprived roots. On the other hand, significantly less ${ }^{59} \mathrm{Fe}$ was taken up by roots and thereby translocated to shoots of $+\mathrm{Fe}$ plants. Uptake and translocation of ${ }^{59} \mathrm{Fe}$ from Humiron ${ }^{\circledR}$ did not differ in principle from that of Fe-EDDHA complex (Fig. 2). Utilization of ${ }^{59} \mathrm{Fe}$ from ${ }^{59} \mathrm{Fe}$-labelled Humiron ${ }^{\circledR}$ was strongly enhanced by a low $\mathrm{pH}$ of the root external solution, the conditions conductive for enhanced reduction of $\mathrm{Fe}^{\mathrm{III}-}$ chelates and thereby root uptake of this micronutrient (Römheld and Marschner, 1994). However, the uptake and especially translocation rates were significantly higher for ${ }^{59} \mathrm{Fe}-\mathrm{EDDHA}$, while the extrapalsmatic $\mathrm{Fe}$ was found to be about 3-4 times higher in the roots exposed to ${ }^{59} \mathrm{Fe}$-humate, indicating higher precipitation of Fe from Humiron ${ }^{\circledR}$ in the root apoplast (Fig. 3). This is in accordance with data of Cesco et al. (2002), which showed a large pool of extraplasmatic Fe formed in cucumber roots after supplying Fe-WEHS complex. Their study also demonstrated that cucumber plants were able to mobilize extraplazmatic ${ }^{59} \mathrm{Fe}$ precipitated after roots being incubated in Fe-WEHS supplied nutrient solution. Remobilization of extraplasmatic $\mathrm{Fe}$ was particularly evident at acidic condition (Bienfait et al., 1985; Zhang et al., 1991; Strasser et al., 1999). Hence, this extraplasmatic Fe pool can act as a good buffer for available $\mathrm{Fe}$ in the rhyzosphere which, depending of the capacity of strategy 1 plant species to acidify rhizosphere, allows the mobilization and translocation to the shoot of considerable amounts of apoplastic Fe. 


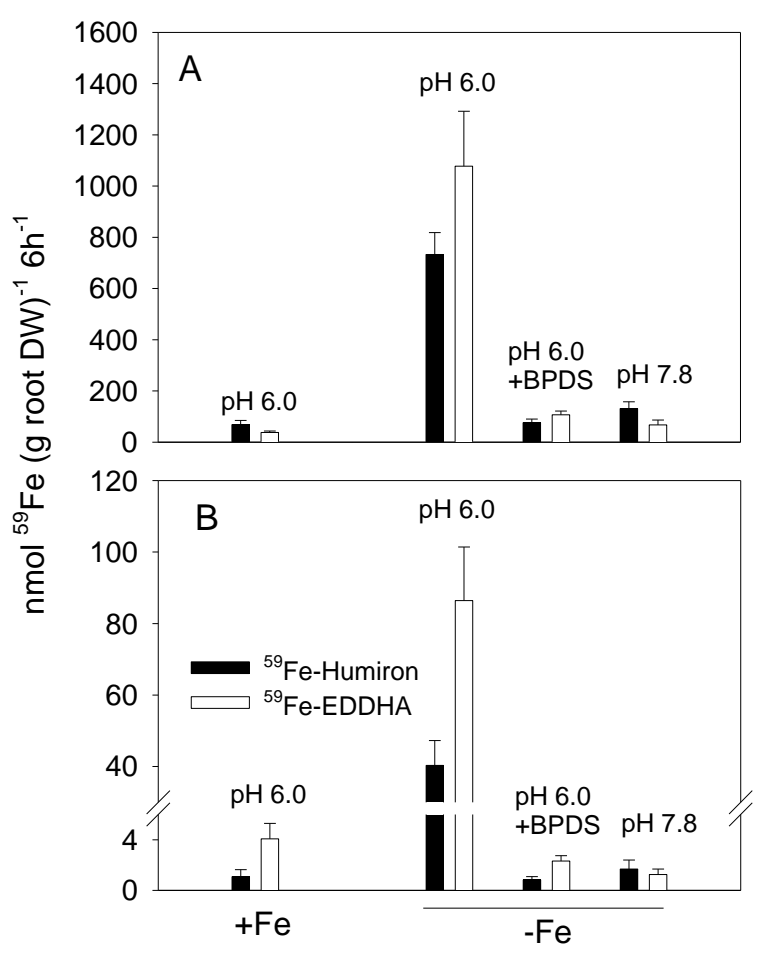

Figure 2. Root uptake (A) and root-to-shoot translocation (B) of ${ }^{59} \mathrm{Fe}$ in $\mathrm{Fe}$-sufficient $(+\mathrm{Fe})$ and $\mathrm{Fe}$-deficient $(-\mathrm{Fe})$ cucumber plants (strategy 1) after 6-h-exposure to ${ }^{59} \mathrm{Fe}$-labelled Humiron ${ }^{\circledR}$ and ${ }^{59} \mathrm{Fe}-\mathrm{EDDHA}$ (control). Translocation rate was calculated as a sum of root and shoot Fe content divided by the root DW.

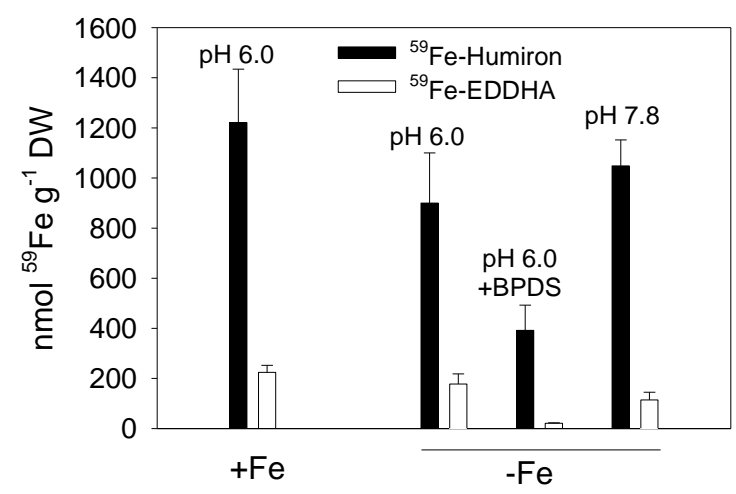

Figure 3. The concentration of extraplasmatic $\mathrm{Fe}$ of $\mathrm{Fe}$-sufficient $(+\mathrm{Fe})$ and $\mathrm{Fe}$-deficient (-Fe) cucumber roots after 6-h-exposure to ${ }^{59} \mathrm{Fe}$-labelled Humiron ${ }^{\circledR}$ and ${ }^{59} \mathrm{Fe}-\mathrm{EDDHA}$ (control).

It is well known that the release of PS shows a diurnal rhythm with a morning maximum and an evening minimum. During the morning experiment barley plants precultured in $-\mathrm{Fe}$ nutrient solution took up about 4 times more $\mathrm{Fe}$ from ${ }^{59} \mathrm{Fe}$ labelled Humiron ${ }^{\circledR}$ as compared either with $+\mathrm{Fe}$ plants (morning experiment) or with $-\mathrm{Fe}$ plants (evening experiment) (Fig. 4A). About $40 \%$ of the total Fe taken up by the roots from Humiron ${ }^{\circledR}$ was translocated to the shoots during 4 hours (Fig. 4B). Addition of deoxymugineic acid (DMA) in the uptake solution at final concentration of $20 \mu \mathrm{M}$ during the evening experiment, increased both uptake and translocation rates of ${ }^{59} \mathrm{Fe}$ in $-\mathrm{Fe}$ plants approaching the levels recorded in the morning experiment (Fig. 4). Addition of DMA also significantly increased ${ }^{59} \mathrm{Fe}$ uptake and translocation by $+\mathrm{Fe}$ plants. Root extraplasmatic Fe in barley (not shown) was found to be about 2 times higher in the conditions with a lack of PS release (evening experiment) than in the uptake solution with high PS concentration (morning experiment or addition of $20 \mu \mathrm{M}$ DMA in the evening).

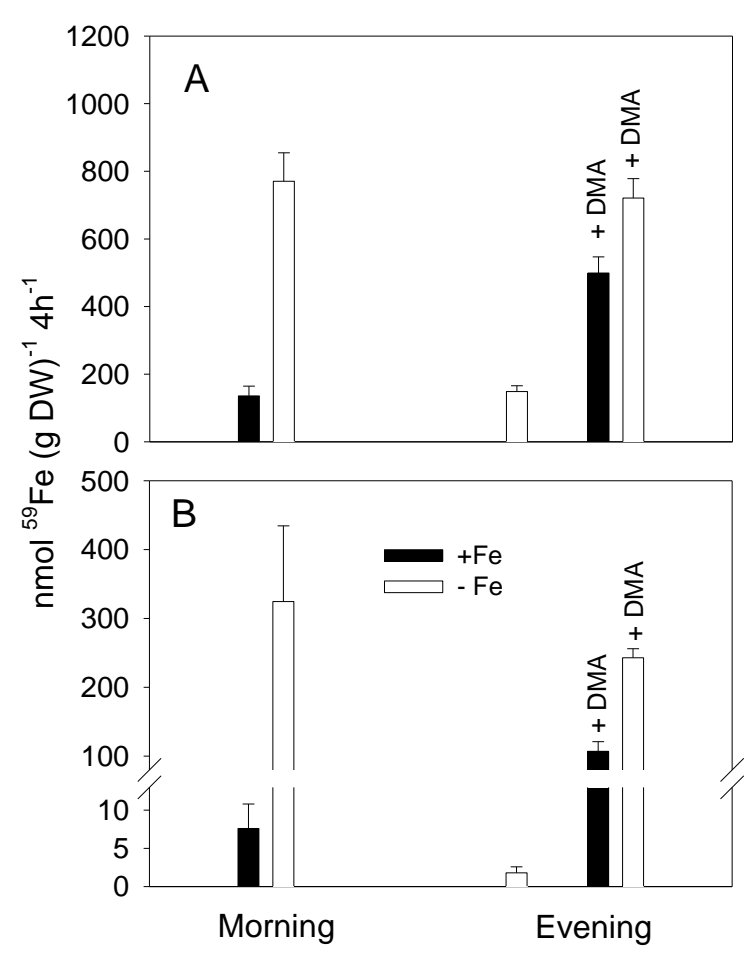

Figure 4. Root uptake (A) and root-to-shoot translocation (B) of ${ }^{59} \mathrm{Fe}$ in $\mathrm{Fe}$-sufficient $(+\mathrm{Fe})$ and Fe-deficient $(-\mathrm{Fe})$ barley plants (strategy 2) after 4-h-exposure to ${ }^{59} \mathrm{Fe}$-labelled Humiron ${ }^{\circledR}$. To prevent latent $\mathrm{Fe}$ deficiency plants were sprayed with $0.3 \%(\mathrm{w} / \mathrm{v})$ $\mathrm{Fe}$-citrate twice daily. DMA was added to the uptake solution at the final concentration of $20 \mu \mathrm{M}$. Morning, period of high root PS release; evening, period of low root PS release. Translocation rate was calculated as a sum of root and shoot Fe content divided by the root DW.

\section{CONCLUSION}

Iron from Humiron ${ }^{\circledR}$ can easily be acquired by strategy 1 plant species (e.g. cucumber) via the reduction of $\mathrm{Fe}^{\mathrm{III}}$-humates by the inducible plasma membrane-bound reductase, similarly to $\mathrm{Fe}$ acquisition from synthetic $\mathrm{Fe}^{\mathrm{III}}$ chletes such as Fe-EDTA or Fe-EDDHA. Strategy 2 plant species (e.g. barley) can also efficiently utilize $\mathrm{Fe}$ from Humiron ${ }^{\circledR}$ via ligand exchange between humates and PS released under Fe deficiency. Thus, utilization of $\mathrm{Fe}$ from Humiron ${ }^{\circledR}$ is comparable to the utilization 
of $\mathrm{Fe}$ bound to water-extractable humic substances (extracted from peat) as has previously been reported by Cesco et al. (2002). There is a high potential for application of natural-based Fe-chelates such as Humiron ${ }^{\circledR}$ in organic crop production, as these chelates are more biodegradable than the synthetic ones, and therefore environmentally benign.

\section{REFERENCES}

Awad, F., Römheld, V., \& Marschner, H. 1988. Mobilization of ferric iron from a calcareous soil by plant-borne chelators (Phytosiderophores). Journal of Plant Nutrition, 11(6-11), pp. 701-713. doi:10.1080/01904168809363835

Bienfait, H.F., van den Briel, W., \& Mesland-Mul, N.T. 1985. Free Space Iron Pools in Roots: Generation and Mobilization. Plant Physiology, 78(3), pp. 596-600. doi:10.1104/pp.78.3.596

Cesco, S., Römheld, V., Varanini, Z., \& Pinton, R. 2000. Solubilization of iron by water-extractable humic substances. Journal of Plant Nutrition and Soil Science, 163(3), pp. 285-290. doi:10.1002/15222624(200006)163:3<285::aid-jpln285>3.0.co;2-Z

Cesco, S., Nikolic, M., Römheld, V., Varanini, Z., \& Pinton, R. 2002. Uptake of ${ }^{59} \mathrm{Fe}$ from soluble ${ }^{59} \mathrm{Fe}$-humate complexes by cucumber and barley plants. Plant and Soil, 241(1), pp. 121128. doi:10.1023/a:1016061003397

Hördt, W., Römheld, V., \& Winkelmann, G. 2000. Fusarinines and dimerum acid, mono- and dihydroxamate siderophores from Penicillium chrysogenum, improve iron utilization by strategy I and strategy II plants. BioMetals, 13, 37-46.
Marschner, H., \& Römheld, V. 1994. Strategies of plants for acquisition of iron. Plant and Soil, 165(2), pp. 261-274. doi:10.1007/bf00008069

Nikolic, M., Cesco, S., Römheld, V., Varanini, Z., \& Pinton, R. 2003. Uptake of Iron $\left({ }^{59} \mathrm{Fe}\right)$ complexed to water-extractable humic substances by sunflower leaves. Journal of Plant Nutrition, 26(10-11), pp. 2243-2252. doi:10.1081/pln120024278

Nikolic, M., Cesco, S., Römheld, V., Varanini, Z., \& Pinton, R. 2007. Short-term interactions between nitrate and iron nutrition in cucumber. Functional Plant Biology, 34(5), pp. 402-408. doi:10.1071/fp07022

Nikolic, M., \& Pavlovic, J. 2018. Plant responses to iron deficiency and toxicity and iron use efficiency in plants. In A.M. Hossain et al. Eds., Plant Micronutrient Use Efficiency: Molecular and Genomic Perspectives in Crop Plants, pp. 5569. San Diego: Academic Press.

Pinton, R., Cesco, S., Santi, S., Agnolon, F., \& Varanini, Z. 1999. Water extractable humic substances enhance iron deficiency responses to Fe-deficient cucumber plants. Plant and Soil, 210(2), pp. 145-157. doi:10.1023/a:1004329513498

Römheld, V., \& Nikolic, M. 2006. Iron. In A. Barker \& D. Pilbeam Eds., Handbook of Plant Nutrition. Boca Raton: CRC Press., pp. 329-350. doi:10.1201/9781420014877.ch11

Strasser, O., Köhl, K., \& Römheld, V. 1999. Overestimation of apoplastic $\mathrm{Fe}$ in roots of soil grown plants. Plant and Soil, 210(2), pp. 179-189. doi:10.1023/a:1004650506592

Zhang, F.S., Romheld, V., \& Marschner, H. 1991. Role of the root apoplasm for iron acquisition by wheat plants. Plant Physiology, 97(4), pp. 1302-1305. doi:10.1104/pp.97.4.1302 